\title{
A Rare Case in Rheumatology Clinical Practice: Pachydermodactyly
}

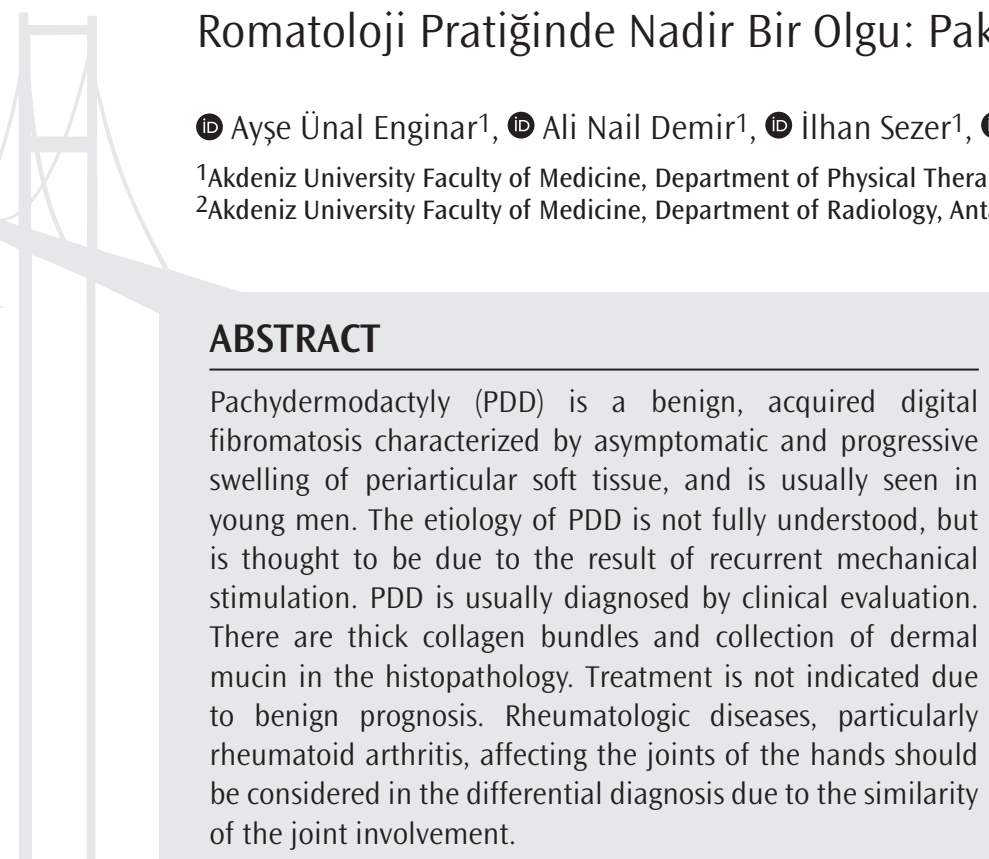

Keywords: Pachydermodactyly, proximal interphalangeal joint, painless swelling
öZ

Pakidermodaktili (PDD), genellikle genç erkeklerde görülen, periartiküler yumuşak dokunun asemptomatik, ilerleyici șişliği ile karakterize benign edinsel dijital fibromatozdur. PDD'nin etiyolojisi tam olarak bilinmemekle beraber muhtemelen tekrarlayan mekanik stimülasyonun bir sonucudur. Tanı genellikle klinik olarak konur. Histopatolojide kalın kollajen demetleri ve dermal musin birikimi vardır. Benign seyir gösterdiğinden tedavi genellikle endike değildir. Başta romatoid artrit olmak üzere el eklemlerini etkileyen romatizmal hastalıklar, eklem tutulumunun benzerliğinden dolayı, ayırıcı tanıda düşünülmelidir.

Anahtar Kelimeler: Pakidermodaktili, proksimal interfalangial eklem, ağrısız șişlik

\section{Introduction}

Pachydermodactyly (PDD) is a benign, skin fibromatosis characterized by asymptomatic painless periarticular swelling in the proximal interphalangeal (PIP) and sometimes metacarpophalangeal (MCP) joints, often affecting young adult males. The etiology is not fully understood, but mechanical trauma is thought to be responsible. Histopathologically, there is an accumulation of dermal collagen histopathologically (1). Rheumatological diseases, particularly rheumatoid arthritis (RA), affecting the joints of the hands should be considered in the differential diagnosis due to the similarity of the joint involvement (2).

We would like to draw attention to this rare situation, which should be considered in rheumatology clinical practice as it causes painless joint swelling.

\section{Case Report}

A 22-year old male patient was referred to our outpatient clinic with the complaint of swelling of the $3^{\text {rd }}$ PIP joint of the right hand for the last 2.5 years. Symmetrical swelling was observed around the PIP joints of digits 3-4 bilaterally (Figure 1).

The patient had previously undergone methotrexate treatment in another medical center with the diagnosis of RA, but the patient discontinued the treatment on his own request as no benefit was obtained. There was no pain in the joints of the hands, no morning stiffness and no night pain. The results of the systemic examinations were unremarkable. There was no family history of psoriasis or rheumatologic disease. On the physical examination, there were joint swellings in the $4^{\text {th }}$ and more evidently in the $3^{\text {rd }}$ PIP joints of the right hand and the $3^{\text {rd }}$ and $4^{\text {th }}$ PIP joints of the left hand. There was no tenderness with palpation and range of motion was complete. In the laboratory tests, the results of the complete blood count, liver function tests, kidney function tests, erythrocyte sedimentation rate, C-reactive protein, thyroid stimulating hormone test and urinalysis were normal. Hepatitis markers, antinuclear antibody, rheumatoid factor, anti-cyclic and citrullinated peptide antibody were negative. Periarticular soft tissue swelling was observed on the direct 


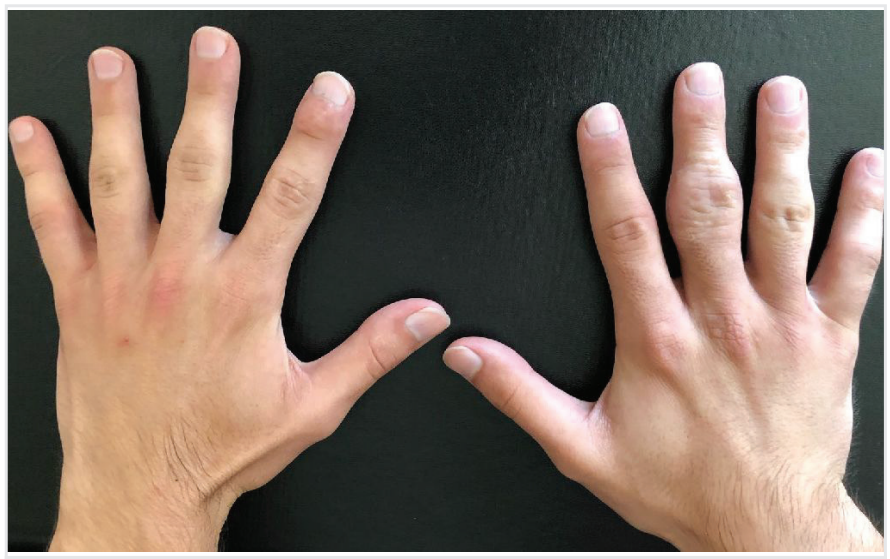

Figure 1. Photographic image of bilateral hands. Symmetrical swelling around proximal interphalangeal joints of digits 3-4 bilaterally

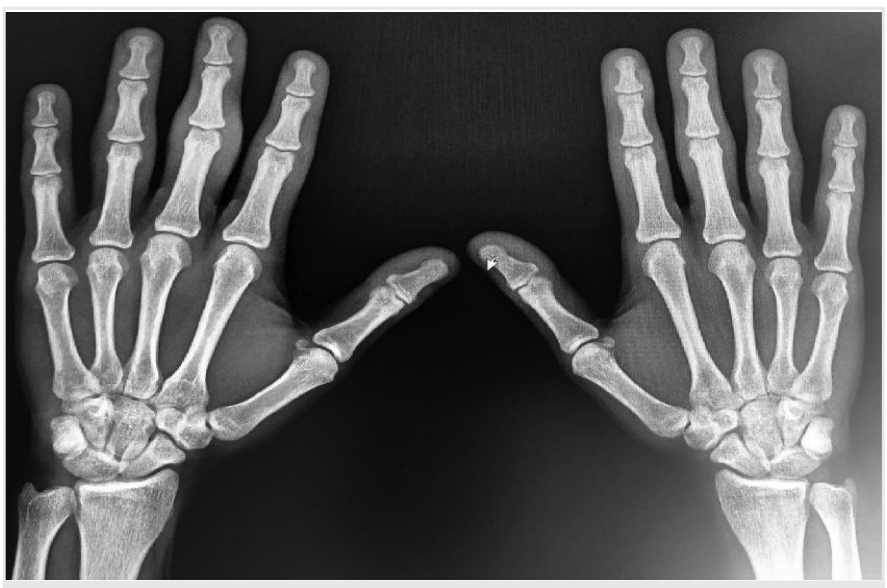

Figure 2. Hand radiograph showings soft tissue swelling around the proximal interphalangeal joints without joint narrowing or bony erosions

radiograph, but there was no sclerosis, joint space narrowing, erosion or periosteal reaction (Figure 2).

There was no evidence of inflammation in the PIP joint on ultrasonographic evaluation. Thickening of the subcutaneous tissue was detected on magnetic resonance imaging (MRI) of the hand, but no evidence could be associated with synovitis (Figure 3).

A biopsy was performed from the lateral of the $3^{\text {rd }}$ PIP joint of the right hand with a preliminary diagnosis of PDD, and hyperkeratosis and thickened dermis with collagen deposition were detected (Figure 4).

The patient was diagnosed with PDD after evaluation of the clinical, laboratory, radiology and biopsy findings. The patient was given information that PDD is a non-inflammatory disease with a benign course.

Written informed consent was obtained from the patient for details to be published in this study.

\section{Discussion}

PDD is a rare digital fibromatosis, which was first reported by Basex et al. (3) in 1973 and was then named PDD by Verbov (4) in 1975. To date, approximately 150 cases of PDD have been reported in literature

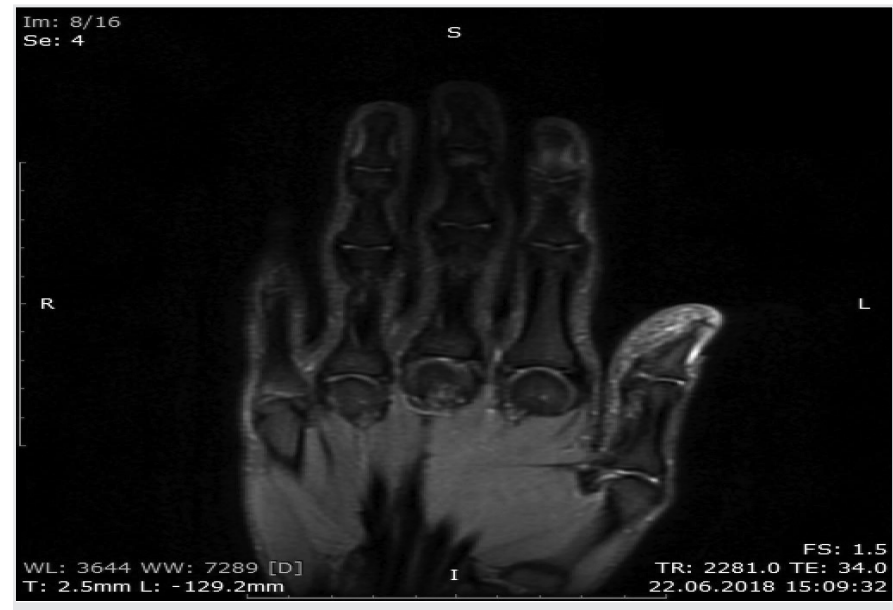

Figure 3. Magnetic resonance imaging reveals soft tissue swelling of the third to fourth proximal interphalangeal joints of the hand without articular or bony abnormality

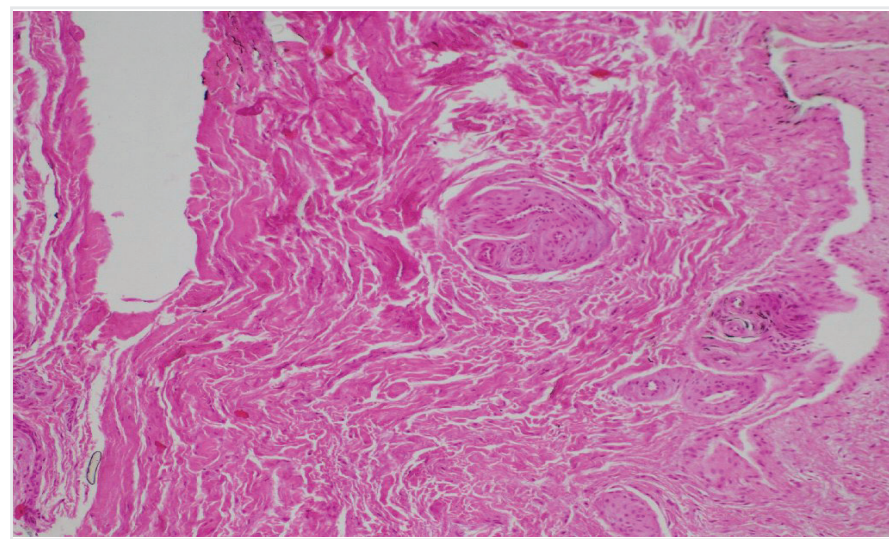

Figure 4. Skin biopsy specimen exhibits marked hyperkeratosis and thickened dermis with collagen deposition (hematoxylin and eosin, x100)

(5). It is characterized by soft tissue swelling especially in the lateral part of the PIP joints of the $2^{\text {nd }}-4^{\text {th }}$ fingers of adolescent males. It is approximately 4 times more commonly in men (2). There are also familial cases as case reports in the literature (6). Although the etiology is not fully understood, mechanical trauma is a precipitating factor in $44 \%$ of patients (2). Continuous pulling and docking of the fingers can be seen in some occupations (athletes, musicians, computer users, farm workers) and also in subjects with Asperger syndrome and obsessive compulsive disorder. Therefore, a psychiatric consultation is essential $(1,7)$. Bardazzi et al. (8) defined PDD in 5 subtypes: a) classical (which affects multiple joints and is due to repeated microtrauma, b) localized (which affects only one joint), c) transgradient (which affects the dorsum of the hand and MCP areas), d) familial and e) the form associated with tuberous sclerosis.

There is no specific laboratory finding for the diagnosis. The acute phase proteins are normal and there are no specific autoantibodies for the disease. No periarticular osteoporosis, periosteal reaction, erosion, osteophyte or cysts are observed on radiographs, only soft tissue swelling. No pathological findings such as synovitis, capsulitis, tendinitis or hypervascularization apart from soft tissue swelling are found on MRI screening (9). In histopathological examination, PDD is characterized by hyperkeratosis and achantosis of the epidermis, and 
thick collagen bundles and increased fibroblasts in the dermis. The cytological appearance of the fibroblasts is benign. There may also be mucin accumulation in the interstitium in varying degrees and the number of elastic fibers may be decreased (10). When collagen analysis is performed, the amount of collagen type 3 and 5 is higher. Collagen fibers are less uniform and of smaller diameter in electronmicroscopy $(1,2)$.

Chen et al. (1) proposed the diagnostic criteria of no symptom of the patient, no morning stiffness, no pain with movement and tenderness with palpation, finger swelling especially on the ulnar or radial side, but not peripheral, normal laboratory test results, and only soft tissue swelling on X-ray.

In the differential diagnosis, there should be consideration of rheumatologic diseases such as juvenile idiopathic arthritis and RA, bone diseases such as spina ventosa, and pachydermatoperiostosis (11), skin diseases such as knuckle pads (12) and foreign body granuloma, and genetic causes such as Thiemann's disease (2).

There is no universally accepted treatment option. It may be useful to avoid mechanical stimulation. Some cases improved with oral tranilast, intralesional triamcinolone injection and surgical excision of fibrotic tissues. Tranilast is an anti-allergic drug, which inhibits collagen synthesis $(13,14)$. No treatment was applied to the current patient, but as he had a habit of pulling his fingers, he was advised to discontinue this habit. The patient was referred to the psychiatry clinic for consultation.

PDD is a rare benign disease. As it causes swelling in the PIP joints, differential diagnoses must consider rheumatologic diseases, primarily RA. Loss of function, restricted range of motion, no morning stiffness and no pathology determined with laboratory and imaging methods, are significant characteristics. Correct recognition of PDD prevents unnecessary referrals and tests and, most importantly, inappropriate treatment.

Informed Consent: Written informed consent was obtained from the patient for details to be published in this study.

Peer-review: Externally and internally peer-reviewed.

Author Contributions: Concept - A.Ü.E., A.N.D., I.S., C.Ç.; Design - A.Ü.E., A.N.D., I.S., C.Ç.; Supervision - A.Ü.E., A.N.D., I.S., C.Ç.; Data Collection and/or Processing - A.Ü.E., I.S.; Analysis and/ or Interpretation - A.Ü.E.,
A.N.D., I.S., C.Ç.; Literature Search - A.Ü.E., I.S., C.C.; Writing Manuscript - A.Ü.E., I.S.; Critical Review - I.S., C.Ç.

Conflict of Interest: No conflict of interest was declared by the authors.

Financial Disclosure: The authors declared that this study received no financial support.

\section{References}

1. Chen CK, Shyur SD, Chu SH, Huang LH, Kao YH, Liu LC. Pachydermodactyly: three new cases in Taiwan. J Microbiol Immunol Infect 2015; 48: 340-4.

2. Dallos T, Oppl B, Kovács L, Zwerina J. Pachydermodactyly: a review. Curr Rheumatol Rep 2014; 16: 442.

3. Basex A, Dupre A, Teillard J. Pachydermie digitale des premieres phalanges par hyperplasie conjonctive dermique et aplasie hypodermique. Bull Soc Fr Dermatol Syphiligr 1973; 80: 455-6.

4. Verbov J. Letter: Pachydermodactyly: a variant of the true knuckle pad. Arch Dermatol 1975; 111: 524.

5. Żuber Z, Dyduch G, Jaworek A, Turowska-Heydel D, Sobczyk M, BanachGórnicka M, et al. Pachydermodactyly-a report of two cases. Reumatologia 2016; 54: 136-40.

6. Russo F, Rodriguez-Pichardo A, Camacho F. Familial pachydermodactyly Acta Derm Venereol 1994; 74: 386-7.

7. Woodrow SL, Burrows NP. Pachydermodactyly in association with Asperger syndrome. Clin Exp Dermatol 2003; 28: 674-5.

8. Bardazzi F, Neri I, Raone B, Patrizi A. Pachydermodactyly: seven new cases. Ann Dermatol Venereol 1998; 125: 247-50.

9. Paravina M, Stanojevic M, Jovanovic D, Ljubisavljevic D. Pachydermo-dactyly: a case report and literature review. Serbian Journal of Dermatology and Venereology 2014; 6: 174-85.

10. James WP, Hosler AH. Pachydermodactyly, in Weedons Skin Pathology. Churchill Livingstone Elsevier, 4th edition. Edinburgh, Scotland; 2016.

11. Rai A, Zaphiropoulos GC. An unusual case of peri-articular soft tissue finger swelling in an adolescent male: pachydermodactyly or pachydermoperiostosis? Br J Rheumatol 1994; 33: 677-9.

12. Chamberlain AJ, Venning VA, Wojnarowska F. Pachydermodactyly: a form fruste of knuckle pads? Australas J Dermatol 2003; 44: 140-3.

13. Plana Pla A, Bassas Vila J, Toro Montecinos MA, Ferrandiz Foraster C. Pachydermodactyly successfully treated with triamcinolone injections. Actas Dermosifiliogr 2014; 105: 319-21.

14. Higuchi C, Tomita T, Yoshikawa H. Pachydermodactyly treated with tranilast in a young girl. Case Rep Orthop 2014; 2014: 132854. 